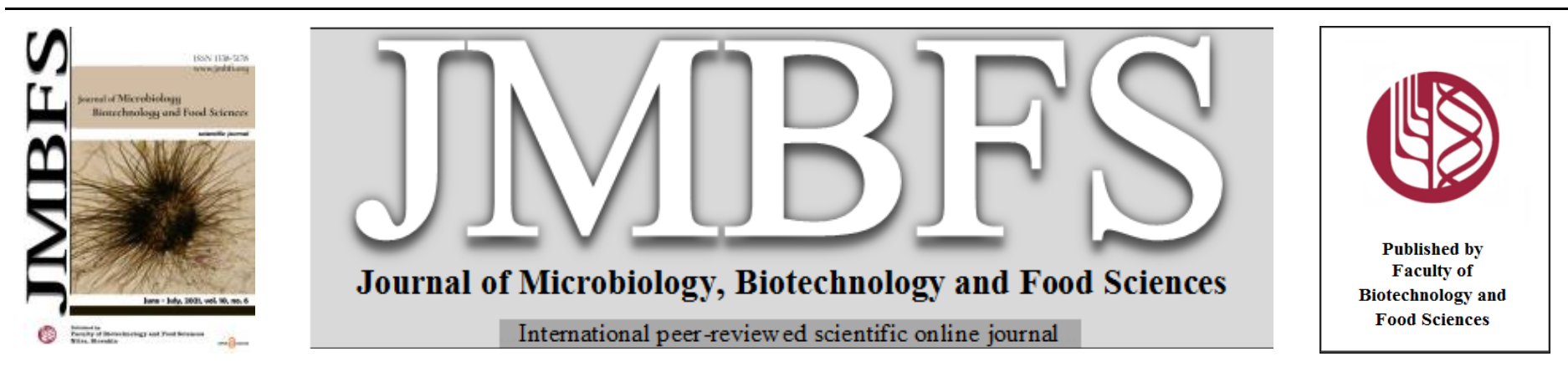

\title{
EVALUATION OF THE DOMINANT PROTEIN FROM WHOLE-CELL HEATING METHOD USING MALDI-TOF/TOF MASS SPECTROMETRY
}

\author{
Siti Gusti Ningrum* $*^{1}$, I Wayan Teguh Wibawan ${ }^{2}$
}

\author{
Address(es): \\ ${ }^{1}$ Universitas Wijaya Kusuma Surabaya, Faculty of Veterinary Medicine, Surabaya, 60225, Indonesia. \\ ${ }^{2}$ IPB University, Department of Animal Disease and Veterinary Public Health, Bogor, 16680, Indonesia.
}

*Corresponding author: sitiningrum@uwks.ac.id

https://doi.org/10.15414/jmbfs.3807

\section{ARTICLE INFO}

Received 8. 10. 2020

Revised 20. 1. 2021

Accepted 21. 1. 2021

Published 1. 6. 2021

Short communication

open $\odot$ access

\begin{abstract}
Immunoglobulin $\mathrm{G}$ (IgG) are the essential tools in diagnostic kits. The whole-cell is still considered to be used for animal's immunization to produce IgG. The goal of this study was to determine dominant protein on the Shiga toxin-producing Escherichia coli (STEC) O157:H7-induced typical antibody response also determined by MALDI-TOF/TOF mass spectrometry. The heating method was conducted at $71^{\circ} \mathrm{C}$ and $83^{\circ} \mathrm{C}$ for antigen preparation. The proteins were characterized using SDS-PAGE and evaluated by MALDITOF/TOF mass spectrometry. The present study reported that the dominant polyclonal antibody inducing protein was ompC E. coli. The evaluation of mass spectra by MALDI-TOF/TOF might help to identify the dominant polyclonal antibody inducing protein in future preparation of diagnostic kits.
\end{abstract}

Keywords: STEC O157:H7, MALDI-TOF/TOF, SDS-PAGE, ompC

\section{INTRODUCTION}

Antibody of animal origin is important for a wide range of applications, in particular as a research tool for the target detection of pathogenic bacteria such as STEC O157:H7 (Hassan et al., 2015). One of the most important foodborne pathogens for human hemorrhagic colitis (HC) and hemolytic uremic syndrome (HUS) is STEC O157:H7 (Hessain et al., 2015). Since the identification of this serotype, its isolation from clinical samples, in particular from human and animal diarrhea, has increased dramatically (Sharapov et al., 2016). Rapid detection of STEC O157:H7 contamination would be useful to identify STEC O157:H7 in samples. Immunoassay technique is a popular technique to develop detection methods (Haddad et al., 2016). Therefore, antibody production is needed to fulfil the development of immunoassay. One of the conditions for producing the antibody is the antigen used must be immunogenic and has a unique characteristic (Kramer et al., 2017). The whole-cell is widely used for immunization in rabbit to produce polyclonal antibodies. It contains an outer membrane protein $\mathrm{C}$ (ompC), which is a unique receptor to $E$. coli isolates (Wang et al., 2015).

On the other hand, ompC can be used as a target for detection pathogenic E. coli strains since ompC is the critical receptor especially for phage binding (Jawad and Al-Charrakh, 2016; Washizaki et al., 2016). The weakness of using the whole-cell to produce polyclonal antibody is not only anti-antigen target but also anti-non-antigen target will be produced during immunization. Thus, the antigen preparation and identification of polyclonal antibody inducing protein against STEC O157:H7 were applied in the present study. This report may improve in the future preparation of diagnostic kits.

\section{MATERIAL AND METHODS}

Test strain

A STEC O157:H7 isolate was used for antigen preparation. The isolate had been identified and as collections of Microbiology Laboratory in The Faculty of Veterinary Medicine, IPB University.

\section{STEC 0157:H7 protein preparation}

Protein was prepared as previously described by (Westerman et al., 1997) with modification. STEC 0157:H7 isolate was inoculated into $50 \mathrm{~mL}$ broth brain heart infusion (BHI) and incubated at $150 \mathrm{rpm}$ at $37{ }^{\circ} \mathrm{C}$ for $24 \mathrm{~h}$ on incubator shaker
(Amerex, California). The cells were harvested at $4500 \mathrm{~g}$ for $15 \mathrm{~min}$ by centrifugation (Heraeus, Germany). The pellets were washed with phosphate buffer saline three times (PBS; pH 7.4). The STEC O157:H7 pellets were suspended in PBS ( $\mathrm{pH} 7.4)$. Protein in the sample was measured using the Bradford technique and red using densitometer at optical density $620 \mathrm{~nm}$. Samples were diluted with PBS at $0.5 \mathrm{mg} / \mathrm{ml}(\mathrm{pH} 7.4)$. Two protein preparation methods were applied, including boiling at $71{ }^{\circ} \mathrm{C}$ (T1) and $83{ }^{\circ} \mathrm{C}$ (T2) for $1 \mathrm{~h}$, respectively. Protein was measured on $12 \%$ sodium dodecyl sulphate polyacrylamide gel electrophoresis (SDS-PAGE) (Amersham ECL 12\%, USA).

\section{Protein identification}

The protein samples were digested with trypsin and peptides were extracted using standard techniques (Bringans et al., 2008). The peptides were analyzed using a 5800 Proteomics Analyzer [AB Sciex] using the MALDI-TOF/TOF TOF mass spectrometer. Spectra was analyzed using Mascot sequence matching software [Matrix Science] with the MSPnr100 Database to identify the protein of interest.

\section{Evolutionary relationships of taxa}

The history of evolution was inferred using the method of Neighbor-Joining (Saitou and Nei, 1987). The optimal tree is displayed with the branch length sum of $=2.54683782$. The percentage of replicate trees in which the related taxa in the bootstrap test are clustered together (1000 replicates) is shown next to the branches (Felsenstein, 1985). With branch lengths in the same units as those of the evolutionary distances used to infer the phylogenetic tree, the tree is drawn to scale. Using the Poisson correction method, evolutionary distances were computed (Zuckerkandl and Pauling 1965).

In addition, the number of amino acid substitutions per site is represented in the units. A total of 6 amino acid sequences were involved in this analysis. For each sequence pair, all ambiguous positions were removed for (pairwise deletion option). In the final dataset, there were a total of 378 positions. In MEGA X, evolutionary analyses have been performed (Kumar et al., 2018).

\section{RESULTS AND DISCUSSION}

In the present study, the proteins produced by the whole-cell heating method were evaluated. By SDS-PAGE, the $71{ }^{\circ} \mathrm{C}$ heating method yielded more protein than the $83{ }^{\circ} \mathrm{C}$ heating method (Figure 1). Temperature of $71{ }^{\circ} \mathrm{C}$ used in this study was the optimum temperature for killing STEC 0157:H7 (Ryan et al., 
1986) which was required in antigen preparation for immunization in animals. On the other hand, $83{ }^{\circ} \mathrm{C}$ was the temperature to obtain at least one band left with molecule weight of $58.6 \mathrm{kDa}$ in $12 \%$ SDS-PAGE in this study (Figure 1). Figure 1 showed more bands at $71{ }^{\circ} \mathrm{C}$ than $83{ }^{\circ} \mathrm{C}$ indicated elevated temperatures denatured more proteins whereas proteins will be damaged or unfolded by elevated temperatures during heat-shock (Sottile $\boldsymbol{e t}$ al., 2018). Specific band was needed to decrease non-target antigen in polyclonal antibody production. Thus, in the present study a specific band found on both temperature treatment was investigated. Heating method was used to obtain antigen for antibody production with fast and inexpensive way to get a wide variety of possible strategies of STEC O157:H7 antigen. This method was widely used in antigen preparation to produce antibody against microorganism (Michael et al., 1962; Evelyn 1971; Penner and Hennessy 1980; Westerman et al., 1997; Haas et al., 2005; Nakatsuji et al., 2008).

According to MALDI-TOF/TOF mass spectrometry analysis and MSPnr100 Database search using Mascot software the investigated strain could be identified as ompC E. coli with score of 964 (Figure 2). ompC is an important candidate antigen for the development of bacterial pathogens defense strategies since the position of the outer membrane protein as interfaces between the cell and the environment, (Molloy et al., 2000). Jawad and Al-Charrakh (2016) also considered that some of outer membranes have a unique characteristic. Although ompC can be used as the protein target for polyclonal antibodies production, the result indicated that there was a potential for cross reaction between Enterobactericeae. Sequencing amino acid revealed a sequence identity of $100 \%$, $99.53 \%, 99.25 \%, 98.67 \%, 98.59 \%, 98.35 \%$ to the respective sequences of type protein ompC of E. coli, Shigella flexneri, Salmonella enterica, Klebsiella pneumoniae, Campylobacter jejuni and ompC E. coli O157:H7. The dendrogram of the sequencing results of amino acid was shown in Figure 3 Therefore, it could be assumed that the potential cross-reaction between Enterobactericeae regarding antigen preparation procedure and using standalone whole-cell inactivation could raise the possibility of the cross-reaction. A similar concern of cross-reactivity has been reported for dog infections with Borrelia burgdorferi and B. turicatae (Gettings et al., 2019). Cross-reactivity with Tick-borne relapsing fever caused by $B$. turicatae can confuse the veterinarians for prevention and control. Our results highlight the concerns over using specific antigens and help inform future research on cross-reactivity to specific antigens.

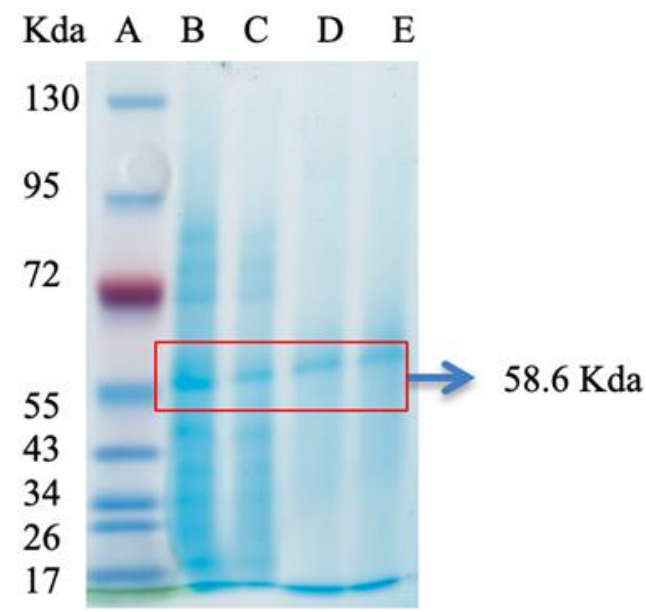

Figure 1 Antigen protein profile for heated method as evaluated by $12 \%$ polyacrylamide gel electrophoresis; (A) Broad range protein marker; (B, C) STEC O157:H7 heated for $71^{\circ} \mathrm{C}$ (T1); (D, E) STEC O157:H7 heated for $83^{\circ} \mathrm{C}$ (T2).

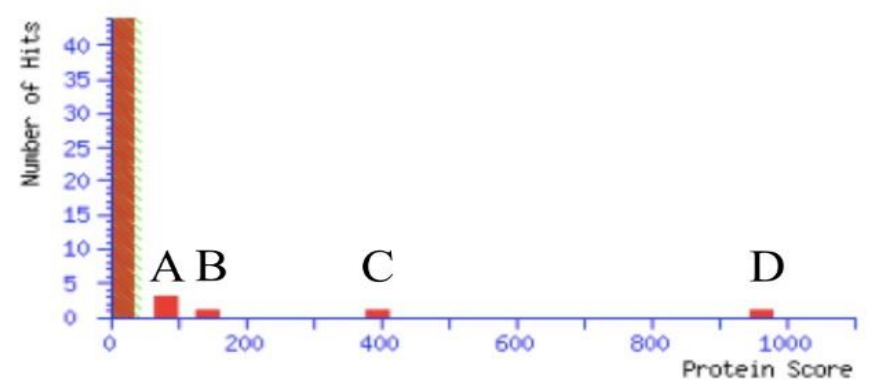

Figure 2 Mascot score histogram of MADITOF/TOF. (A) ompF E. coli O145:H28, score $=57$; $(\mathrm{B})$ outer membrane porin protein E. coli strain SE11, score $=117$; (C) outer membrane porin C E. coli $\mathrm{DEC} 1 \mathrm{E}$, score = 399; (D) ompC E. coli, score $=964$. (The score of Ions is $-10 * \log (\mathrm{P})$, where $\mathrm{P}$ is likely to be a random event for the observed match. The score of individual ions $>45$ shows identity or extensive homology $(\mathrm{p}<0.05)$. As a non-probabilistic base for ranking protein hits, protein scores are derived from ion scores.

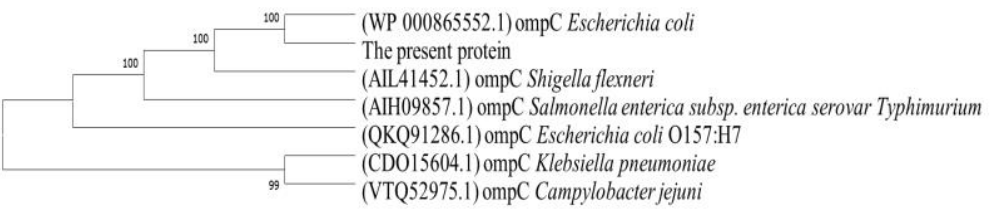

Figure 3 Dendrogram analysis of ompC of the present protein, E. coli $\mathrm{O} 157: \mathrm{H} 7$ and other ompC of gram negative bacteria from NCBI GenBank.

\section{CONCLUSION}

Antigen preparation using standalone heating whole-cell of bacteria E. coli O157:H7 is not recommended for antibody production. Despite the advantages of using whole-cell for antibody production, the risk of cross-reactivity can become a problem. Cross-reactivity could raise confusion of users for prevention and control. MALDI-TOF/TOF and comparing the protein by the phylogenetic tree are essential methods for investigating antigens' cross-reactivity.

Acknowledgments: The authors would like to thank Dr. Rahmat Setya Adji for supporting and providing opportunity to conduct the present study.

\section{REFERENCES}

Bringans, S., Eriksen, S., Kendrick, T., Gopalakrishnakone, P., Livk, A., Lock, R., \& Lipscombe, R. (2008). Proteomic analysis of the venom of Heterometrus longimanus (Asian black scorpion). Proteomics, 8(5), 1081-1096 https://doi.org/10.1002/pmic.200700948.

Evelyn, T. P. T. (1971). The agglutinin response in sockeye salmon vaccinated intraperitoneally with a heat-killed preparation of the bacterium responsible for salmonid kidney disease. Journal of Wildlife Diseases, 7(4), 328-335. https://doi.org/10.7589/0090-3558-7.4.328

Felsenstein, J. (1985). Confidence limits on phylogenies: an approach using the bootstrap. Evolution, 39(4), 783-791. https://doi.org/10.1111/j.1558 5646.1985.tb00420.x.

Gettings, J. R., Lopez, J. E., Krishnavahjala, A., Armstrong, B. A., Thompson, A. T., \& Yabsley, M. J. (2019). Antibodies to Borrelia turicatae in experimentally infected dogs cross-react with Borrelia burgdorferi serologic assays. Journal of Clinical Microbiology, 57(9), e00628-19. https://doi.org/10.1128/JCM.00628-19. Haas, K. M., Poe, J. C., Steeber, D. A., \& Tedder, T. F. (2005). B-1a and B-1b cells exhibit distinct developmental requirements and have unique functional roles in innate and adaptive immunity to $S$. pneumoniae. Immunity, 23(1), 7-18 https://doi.org/10.1016/j.immuni.2005.04.011.

Haddad, M., Soukkarieh, C., Khalaf, H. E., \& Abbady, A. Q. (2016). Purification of polyclonal IgG specific for Camelid's antibodies and their recombinan nanobodies. Open Life Sciences, 11(1), 1-9. https://doi.org/10.1515/biol-20160001 .

Hassan, A. R. H. A. A., de la Escosura-Muñiz, A., \& Merkoçi, A. (2015). Highly sensitive and rapid determination of Escherichia coli O157: H7 in minced beef and water using electrocatalytic gold nanoparticle tags. Biosensors and Bioelectronics, 67, 511-515.https://doi.org/10.1016/j.bios.2014.09.019.

Hessain, A. M., Al-Arfaj, A. A., Zakri, A. M., El-Jakee, J. K., Al-Zogibi, O. G. Hemeg, H. A., \& Ibrahim, I. M. (2015). Molecular characterization of Escherichia coli O157: $\mathrm{H} 7$ recovered from meat and meat products relevant to human health in Riyadh, Saudi Arabia. Saudi journal of biological sciences, 22(6), 725-729. https://doi.org/10.1016/j.sjbs.2015.06.009.

Jawad, A. A. K., \& Al-Charrakh, A. H. (2016). Outer membrane protein C (ompC) gene as the target for diagnosis of Salmonella species isolated from human and animal sources. Avicenna Journal of Medical Biotechnology, 8(1), 42 PMID: 26855735; PMCID: PMC4717466.

Kramer, C. S. M., Roelen, D. L., Heidt, S., \& Claas, F. H. J. (2017). Defining the immunogenicity and antigenicity of HLA epitopes is crucial for optimal epitope matching in clinical renal transplantation. Hla, 90(1), 5-16. https://doi.org/10.1111/tan.13038.

Kumar, S., Stecher, G., Li, M., Knyaz, C., \& Tamura, K. (2018). MEGA X molecular evolutionary genetics analysis across computing platforms. Molecular biology and evolution, 35(6), 1547-1549. https://doi.org/10.1093/molbev/msy096.

Michael, J. G., Whitby, J. L., \& Landy, M. (1962). Studies on natural antibodies to gram-negative bacteria. The Journal of experimental medicine, 115(1), 131146. https://doi.org/10.1084/jem.115.1.131

Molloy, M. P., Herbert, B. R., Slade, M. B., Rabilloud, T., Nouwens, A. S., Williams, K. L., \& Gooley, A. A. (2000). Proteomic analysis of the Escherichic coli outer membrane. European journal of biochemistry, 267(10), 2871-2881. https://doi.org/10.1046/j.1432-1327.2000.01296.x.

Nakatsuji, T., Liu, Y. T., Huang, C. P., Gallo, R. L., \& Huang, C. M. (2008), Antibodies elicited by inactivated Propionibacterium acnes-based vaccines exert 
protective immunity and attenuate the IL-8 production in human sebocytes: relevance to therapy for acne vulgaris. Journal of investigative dermatology, 128(10), 2451-2457. https://doi.org/10.1038/jid.2008.117.

Penner, J. L., \& Hennessy, J. N. (1980). Passive hemagglutination technique for serotyping Campylobacter fetus subsp. jejuni on the basis of soluble heat-stable antigens. Journal of clinical microbiology, 12(6), 732-737. http://doi.org/00951137/80/12-0732/06\$02.00/0.

Ryan, C. A., Tauxe, R. V., Hosek, G. W., Wells, J. G., Stoesz, P. A., McFadden Jr, H. W., ... \& Blake, P. A. (1986). Escherichia coli O157: H7 diarrhea in a nursing home: clinical, epidemiological, and pathological findings. Journal of Infectious Diseases, 154(4), 631-638. https://doi.org/10.1093/infdis/154.4.631.1 Saitou, N., \& Nei, M. (1987). The neighbor-joining method: a new method for reconstructing phylogenetic trees. Molecular biology and evolution, 4(4), 406425. https://doi.org/10.1093/oxfordjournals.molbev.a040454

Sharapov, U. M., Wendel, A. M., Davis, J. P., Keene, W. E., Farrar, J., Sodha, S., ... \& Braden, C. (2016). Multistate outbreak of Escherichia coli O157: H7 infections associated with consumption of fresh spinach: United States, 2006. Journal of food protection, 79(12), 2024-2030. https://doi.org/10.4315/0362-028X.JFP-15-556.

Sottile, M. L., \& Nadin, S. B. (2018). Heat shock proteins and DNA repair mechanisms: an updated overview. Cell Stress and Chaperones, 23(3), 303-315. https://doi.org/10.1007/s12192-017-0843-4.

Wang, X., Guan, Q., Wang, X., Teng, D., Mao, R., Yao, J., \& Wang, J. (2015). Paving the way to construct a new vaccine against Escherichia coli from its recombinant outer membrane protein $\mathrm{C}$ via a murine model. Process Biochemistry, 50(8), 1194-1201. https://doi.org/10.1016/j.procbio.2015.05.001.

Washizaki, A., Yonesaki, T., \& Otsuka, Y. (2016). Characterization of the interactions between Escherichia coli receptors, LPS and OmpC, and bacteriophage T4 long tail fibers. Microbiologyopen, 5(6), 1003-1015. https://doi.org/10.1002/mbo3.384.

Westerman, R. B., He, Y., Keen, J. E., Littledike, E. T., \& Kwang, J. (1997) Production and characterization of monoclonal antibodies specific for the lipopolysaccharide of Escherichia coli O157.Journal of clinical microbiology, 35(3), 679-684. https://doi.org/0095-1137/97/\$04/00+0.

Zuckerkandl, E., \& Pauling, L. (1965). Evolutionary divergence and convergence in proteins. In Evolving genes and proteins (pp. 97-166). Academic Press. https://doi.org/10.1016/B978-1-4832-2734-4.50017-6. 